\title{
UPAYA PENCAPAIAN TUJUAN PENDIDIKAN ISLAM DALAM PENDIDIKAN NASIONAL DIMASA PANDEMI COVID-19
}

\author{
Fery Diantoro \\ Institut Agama Islam Negeri Ponorogo \\ ferydian11@gmail.com
}

\author{
Endang Purwati \\ Institut Agama Islam Negeri Ponorogo \\ purwatiendang049@gmail.com
}

\author{
Erna Lisdiawati \\ Institut Agama Islam Negeri Ponorogo \\ ernalilis592@gmail.com
}

\begin{abstract}
Starting in early 2020, Indonesia has been living life with the impact of the disaster, namely of the corona virus or also called as covid-19. Activities in various fields, especially education, face various problems in the process, which were initially carried out face-to-faceloffline to online and of course this all affects the system and quality of education. Islamic education which has taken place as an inseparable part of the national education system has also experienced this impact. The writing of this article is to identify the difficulty of Islamic education in national education during the covid-19 pandemic, whose goal is to provide knowledge of the efforts made by Islamic education during the covid-19 pandemic. The results of the discussion show that Islamic education in national education during the covid-19 pandemic develops potential or provides creativity to students, teaches to always try in any activity, strives and prays to God Almighty, is responsible for all activities that should still be carried out. while online, maintain morals, manners, be independent, knowledgeable, and of course must keep the spirit. To optimize the function of Islamic religious education, it is necessary to maximize the program through efforts to equalize peers in schools, support facilities for activities, support from related parties, evaluate
\end{abstract}

Keyword: Islamic Education, National Education, Covid-19.

\begin{abstract}
Abstrak: Mulai awal tahun 2020 Indonesia menjalani hidup dengan adanya dampak musibah yaitu terjangkitnya wabah virus corona atau juga disebut dengan covid-19. Aktivitas diberbagai bidang terutama pendidikan menghadapi berbagai permasalahan dalam prosesnya, yang awalnya dilakukan secara tatap muka/luring menjadi tatap mayaldaring dan tentunya ini semua mempengarui sistem dan mutu pendidikan. Pendidikan Islam yang telah berlangsung menjadi bagian yang tidak terpisahkan dari system pendidikan nasional juga mengalami dampak hal tersebut. Penulisan artikel ini untuk mengidentifikasi sulitnya pendidikan Islam dalam pendidikan nasional di masa pandemi covid-19, yang tujuannya Dapat memberikan pengetahuan upaya yang dilakukan pendidikan Islam di masa pandemic covid-19. Hasil pembahasan menunjukkan bahwa pendidikan Islam dalam pendidikan nasional di masa pandemi covid-19 ini mengembangkan potensi atau memberikan kreativitas kepada peserta didik, mengajarkan agar selalu berusaha dalam kegiatan apapun, berikhtiyar dan berdoa kepada Tuhan yang Maha Esa, bertanggungjawab atas segala kegiatan yang semestinya tetap dilakukan selama daring, tetap menjaga akhlak, sopan santun,
\end{abstract}


mandiri, berilmu, dan tentunya harus tetap semangat. Untuk mengoptimalkan fungsi pendidikan agama Islam tersebut maka perlu dimaksimalkan program melalui upayaupaya kesetaraan sejawat di sekolah, sarana penunjang kegiatan, dukungan dari pihak yang berkaitan, melakukan evaluasi

Kata Kunci: Pendidikan Islam, Pendidikan Nasional, Covid-19

\section{PENDAHULUAN}

Problematika dari dampak covid-19 ini dilakukannya social distancing yang gunanya untuk memutus rantai penyebaran covid-19. Dan covid-19 ini juga berdampak pada bidang pendidikan di Indonesia terutama pada bidang pendidikan Islam. Covid-19 ini juga disebut dengan Novel Coronavirus penyakit yang pertama kali muncul terdapat di kota Wuhan, Cina pada tahun 2019 lalu. Kemudian virus covid-19 menyebar dengan sangat cepat sampai pada akhirnya di Indonesia. Pembelajaran terpaksa harus dialihkan pada pembelajaran online melalui alat komunikasi.

Pendidikan Islam memiliki standard dasar pada kehidupan yaitu sebuah pembiasaan dalam menjalankan aktivitas sehari-hari. Ini menjadi hal yang sangat penting bagi anak dan peserta didik, misalnya anak mengetahui beriman dan bertaqwa kepada Tuhan, berahlak, kreatif, mandiri, dan memiliki rasa bertanggungjawab. Karena pentingnya hal tersebut maka materi dan ajaran Pendidikan Islam tetap dilakukan meskipun dalam pembelajaran online. Pendidikan Islam berjalan dari masa ke masa dan pastinya meninggalkan banyak sejarah. Akan tetapi seiring berjalannya waktu masih saja banyak sekali persoalan timbul dalam pendidikan Islam. Seperti masih terjadinya persoalan dikotomi pendidikan Islam dengan pendidikan nasional, padahal sebenarnaya pendidikan Islam bagian yang tidak terpisahkan dari system pendidikan nasional. Persoalan manajemen juga masih mewarnai proses pendidikan Islam secara kelembagaan.

Muncul adanya perselisihan antara pendidikan Islam dengan pendidikan nasional, dikarenakan pendidikan nasional lebih condong kepada pelajaran-pelajaran umum, sedangkan pada pendidikan Islam sedikit dipelajari. Dari situlah kemudian pemerintah melakukan perubahan pendidikan Islam dalam penyusunan UU Sisdiknas Tahun 2003. Jika dicermati secara mendalam pada penyusunan UU tersebut masih terlihat jika dilakukan dengan seadanya. Usaha dalam perubahan tersebut dilakukan dengan sepotong-sepotong, tidak menyeluruh dikarenakan dari sebagian sistem pendidikan Islam masih belum bisa berjalan dengan profesional.

Dengan adanya pandemi wabah covid-19 ini membuat banyak orang sadar akan pentingnya kesehatan dan juga kebersihan. Islam sangat membantu dalam proses pembentukan kepribadian manusia, untuk menjadikan manusia makmur di dunia dan akhirat. Sebagai seorang muslim, tentunya diajarkan untuk memiliki kehidupan yang bersih, lingkungan yang bersih, karena kebersihan adalah bagian dari iman. Jika tercipta lingkungan yang bersih, pastinya itu bisa menjadi faktor kebahagiaan. Dengan 
lingkungan yang bersih tentunya tubuh menjadi sehat. Dengan tubuh yang sehat, masyarakat dapat beribadah kepada Allah dengan jauh lebih baik.

Dari uraian diatas, adanya kajian yang perlu diperjelaskan kembali yaitu pertama tentang apa saja pengertian dari pendidikan Islam dan juga pendidikan nasional itu yang, kedua apa yang menjadikan adanya keterkaitan masalah covid-19 dengan pendidikan Islam dalam Pendidikan nasional, dan yang, dan ketiga bagaimana upaya pencapaian pendidikan tersebut dalam masa pandemi covid-19 ini. Dari pembahasan itu semua diharapkan mampu memberikan gambaran pengetahuan tentang upaya pendidikan Islam dalam pendidikan nasional pada masa pandemi covid-19.

\section{METODE}

Metode yang digunakan dalam pembahasan upaya pencapaian tujuan Pendidikan Islam dalam Pendidikan nasional di masa pandemi covid-19 ini dengan menggunakan metode kualitatif dengan pendekatan literature review. Data penelitian diperoleh dari berbagai referensi buku, jurnal, dan juga beberapa hasil penelitian yang terkait dengan pembahasan penelitian. Data yang diperoleh kemudian dianalisis sehingga didapatkan pembahasan dan kesimpulan penelitian.

\section{PENGERTIAN PENDIDIKAN ISLAM DAN PENDIDIKAN NASIONAL}

Pendidikan yang pertama yang harus dimiliki adalah iman. Iman adalah materi pendidikan yang wajib ditanamkan didalam diri sebelum otak menerima berbagai banyaknya pendidikan. Rasulullahpun juga mengatakan bahwa imanlah yang menjadi sumber utama didalam diri yang perlu ditanamkan terlebih dahulu. Seperti iman kepada Allah. Pendidikan akan terus berjalan dan terus bergerak untuk memberikan berbagai macam ilmu kepada semua. Yang mana ilmu itu dapat menjunjung tinggi derajat kepada masa depan. ${ }^{1}$

Pendidikan Islam adalah sebuah proses untuk merubah tingkah laku individu pada kehidupan pribadi, masyarakat, dan alam sekitarnya. Dengan cara adanya sebuah pengajaran untuk dijadikan suatu aktivitas yang bersifat dasar dan juga dijadikan untuk berbagai bidang pekerjaan yang bisa dilandasi dengan pendidikan keahlian yang dimiliki. Pendidikan Islam dapat membentuk kepribadian setiap umat muslim. Dan bahkan Pendidikan Islam bisa merubah sikap dan tingkah laku agar sesuai dengan ajaran Islam. Memang pada dasarnya Pendidikan Islam adalah sebagai pembentukan sebuah kepribadian muslim atau pun juga dalam perubahan sikap dan tingkah laku yang sesuai dengan ajaran agama Islam. Dengan tujuannya pun sudah terlihat bahwasannya pendidikan Islam bertujuan untuk membentuk karakter kepribadian setiap muslim, dan

\footnotetext{
${ }^{1}$ Nanang Gojali, Tafsir Dan Hadits Tentang Pendidikan (Bandung: CV. Pustaka Setia, 2013), 189.
} 
juga dapat mengembangkan potensi seluruh manusia baik yang berbentuk rohani maupun jasmani. ${ }^{2}$

Pendidikan Islam juga mempunyai istilah umumnya yaitu kalimat tarbiyah, ta'lim, ta'dib. Kata tarbiyah berasal dari kata rabba, yurabbi, tarbiyah, yang mempunyai arti memelihara, membesarkan, dan mendidik. ${ }^{3}$ Kata lain pendidikan Islam lainnya seperti ta'lim. Secara etimologi, ta'lim yang mempunyai konotasi dalam pembelajaran. Seperti adanya sebuah proses dalam pembelajaran ilmu pengetahuan. Proses pembelajaran atau ta'lim sebagai lambang yang menyatakan didalam Al-Qur'an. Proses pembelajaran yang digunakan dengan pemahaman tentang konsep ilmu pengetahuan yang langsung dari penciptanya. Ta'lim dan $t a$ 'dib mempunyai hubungan yang sama dengan tarbiyah. Jadi pendidikan Islam mempunyai banyak istilah-istilah seperti halnya yang diatas. ${ }^{4}$

Ibnu Faris menjelaskan bahwa pendidikan Islam merupakan adanya bimbingan seseorang dengan memperhatikan segala potensi paedagogik yang dimilikinya. Konsep Pendidikan Islam yaitu yang komprehensif atau mempunyai dan memperlihatkan wawasan yang luas bagi manusia. Yang dapat menumbuhkan keseimbangan antara manusia dengan sang pencipta, dan juga keseimbangan antara manusia yang satu dengan yang lainnya. Dengan begitu, pendidikan Islam sangat dibutuhkan dalam membentuk karakter manusia menjadi lebih baik dengan perbuatan yang baik pula. ${ }^{5}$ Pendidikan Islam juga berupaya menjalankan kegiatan pendidikan agama yang efektif agar dapat mempunyai nilai-nilai agama yang bisa mentransformasikan nilai agama kepada sesama manusia. Dengan begitu seluruh dari aspek kehidupan manusia mendapatkan ilmu ilahiyah yang dapat menonjolkan kepada sifat kerohanian. ${ }^{6}$

Pendidikan nasional merupakan pendidikan yang mempunyai ikatan dengan kebudayaan Indonesia yang berdasarkan Pancasila dan Undang-Undang Dasar 1945. Dalam UU No.20 Tahun 2003 tentang Sisdiknas dijelaskan bahwa pendidikan nasional adalah pendidikan yang berdasarkan Pancasila dan UndangUndang Dasar Negara Republik Indonesia Tahun 1945 yang berakar pada nilai-nilai agama, kebudayaan nasional Indonesia dan tanggap terhadap tuntutan perubahan zaman.

Pendidikan nasional keseluruhannya dipadu dari semua satuan dan kegiatan pendidikan yang berkaitan dengan sistem lainnya untuk tercapainya sebuah tujuan yang telah ditetapkan. Pendidkan nasional berfungsi untuk mengembangkan setiap

\footnotetext{
${ }^{2}$ Robiatul Awwaliyah and Hasan Baharun, "Pendidikan Islam Dalam Sistem Pendidikan Nasional Pendidikan Islam Dalam Sistem Pendidikan Nasional (Telaah Epistemologi Terhadap Problematika Pendidikan Islam)," Jurnal Ilmiah DIDAKTIKA, vol. 19, January 14, 2018, https://doi.org/10.22373/JID.V19I1.4193.

${ }^{3}$ Siti Inayatulloh, "Menimbang Penerapan Pendidikan Islam Dalam Sistem Pendidikan Nasional," Jurnal Manajemen Pendidikan Islam 1, no. 2 (2016): 108.

${ }^{4}$ Inayatulloh, 109.

5 Syaiful Anwar and Agus Salim, "Pendidikan Islam Dalam Membangun Karakter Bangsa Di Era Milenial," Al-Tadzkiyyah: Jurnal Pendidikan Islam 9, no. 2 (January 4, 2019): 242, https://doi.org/10.24042/atjpi.v9i2.3628.

${ }^{6}$ Afiful Ikhwan, "Kajian Sosio-Historis Pendidikan Islam Indonesia Era Reformasi," EDUKASI : Jurnal Pendidikan Islam (e-Journal) 5, no. 1 (October 13, 2017): 18.
} 
kemampuan dan meningkatkan mutu kehidupan masyarakat Indonesia dalam rangka mewujudkan tujuan pendidikan nasional. Pendidikan nasional bahwasannya pendidikan adalah usaha sadar yang dilakukan dengan latihan-latihan untuk mewujudkan proses belajar dan pembelajaran agar peserta didik dapat aktif mengembangkan potensi yang dimilikinya. Dan juga memiliki kekuatan yang berhubungan dengan keagamaan, mandiri, bertanggungjawab, memiliki keterampilan yang juga bermanfaat bagi masa depannya, bangsa, negara dan masyarakat. ${ }^{7}$

\section{PENDIDIKAN ISLAM DALAM PENDIDIKAN NASIONAL DIMASA PANDEMI COVID-19}

Pendidikan Islam memberikan berbagai pengajaran ilmu yang berbasis agama. Untuk mendukung keterlaksanaan sebuah perubahan dalam pendidikan nasional agar pendidikan Islam tidak terlewatkan, maka dalam UU No. 20 Tahun 2003 tentang Sisdiknas pada pasal 37 dijelaskan bahwasannya "Pendidikan nasional wajib memuat pendidikan agama, pendidikan kewarganegaraan, bahasa, matematika, ilmu pengetahuan alam, ilmu pengetahuan sosial, seni, dan budaya, pendidikan jasmani dan olahraga, keterampilan". Artinya bahwa pendidikan Islam diberi kesempatan luas dalam mendukung tercapainya pendidikan nasional. Pada praktiknya pendidikan Islam memberikan bimbingan atau menjadikan seorang pemimpin dalam membentuk perkembangan jasmani maupun rohani peserta didik. ${ }^{8}$

Pendidikan nasional didalam Undang-Undang Sisdiknas pada bab 1 berdasarkan pada Pancasila dan UUD 1945 yang juga mempunyai pokok pada nilai agama dalam kebudayaan nasional Indonesia, serta tanggap terhadap berbagai tuntutan zaman. Pendidikan nasional merupakan sebuah perihal dari pendidikan yang memiliki keterkaitan secara padu untuk mencapai sebuah tujuan dari pendidikan nasional. Dalam UUD 1945 tentang tujuan pendidikan nasional yaitu untuk mencerdaskan anak bangsa. Dari situlah kemudian disesuaikan dengan kepentingan dari tujuan pendidikan tersebut. Pendidikan nasional berfungsi untuk mengembangkan sebuah kemampuan yang dimiliki manusia dan juga membentuk watak serta peradaban bangsa yang mempunyai martabat dalam rangka mencerdaskan kehidupan bangsa.

Demikian yang dimaksud dari tujuan pendidikan nasional diatas yaitu untuk mengembangkan potensi menjadi manusia yang beriman dan bertaqwa pada Tuhan Yang Maha Esa serta ajarannya, berakhlak, kreatif, berilmu, menjadi manusia yang bertanggungjawab, dan lain-lain. Jika dilihat dari pembahasan tentang pendidikan nasional menunjukkan bahwa kental nuansa dengan nilai agamanya. Jadi, dari disini

\footnotetext{
7 Nur Kholis, "Paradigma Pendidikan Islam Dalam Undang-Undang Sisdiknas 2003," Jurnal Kependidikan 2, no. 1 (January 1, 1970): 73, https://doi.org/10.24090/jk.v2i1.542.

${ }^{8}$ Alwazir Abdusshomad, "Pengaruh Covid-19 Terhadap Penerapan Pendidikan Karakter Dan Pendidikan Islam," QALAMUNA: Jurnal Pendidikan, Sosial, Dan Agama 12, no. 2 (June 3, 2020): 110, https://doi.org/10.37680/qalamuna.v12i2.407.
} 
terlihat bahwa pendidikan Islam mempunyai kedudukan yang penting dan juga tidak bisa dipisahkan dengan pendidikan nasional dalam membangun manusia Indonesia. ${ }^{9}$

Undang-undang Nomor 20 tahun 2003 tentang Sistem Pendidikan Nasional, menyatakan bahwa: "Pendidikan nasional berfungsi mengembangkan kemampuan dan membentuk watak serta peradaban bangsa yang bermartabat dalam rangka mencerdaskan kehidupan bangsa, bertujuan untuk berkembangnya potensi peserta didik agar menjadi manusia yang beriman dan bertaqwa kepada Tuhan yang Maha Esa, berakhlak mulia, sehat, berilmu, cakap, kreatif, mandiri, dan menjadi warga negara yang demokratis serta bertanggungjawab". Merujuk pada fungsi pendidikan diatas bahwa pendidikan berfungsi untuk menjadikan peserta didik beriman dan bertaqwa kepada Tuhan yang Maha Esa. Dan itu semua yang Dapat mewujudkan dengan sempurna adalah pendidikan agama khususnya pendidikan agama Islam. Pendidikan Islam membentuk insan kamil dengan mengedepankan nilai-nilai keislaman yang menunjukkan pada perkembangan manusia yang berakhlak mulia serta taat dan patuh terhadap ajaran Islam dan tunduk pada Allah SWT.

Pendidikan Islam didalam pendidikan nasional memiliki posisi penting dalam membangun kemampuan manusia, berpotensi, berakhlak mulia, kreatif dan juga bertanggungjawab dalam membangun kehidupan di bangsa Indonesia. Pendidikan Islam dalam pendidikan nasional di masa pandemi covid-19 ini mempunyai arti-arti penting yaitu: pertama, nilai-nilai yang terkandung didalam Pancasila itu sebagai dasar dengan nilai agama Islam yang berarti tauhid. Di saat covid-19 sekarang ini harus percaya dan yakin pada Allah bahwa Tuhan itu ada. Kedua, tetap menjadi manusia memiliki potensi dan menjadi manusia yang bermartabat baik jasmani maupun rohani. Ketiga, pendidikan memiliki tujuan mengembangkan potensi menjadi manusia yang berakhlak, beriman, bertaqwa pada Tuhan, dan juga memiliki rasa bertanggungjawab.

Dimasa pandemi seperti sekarang ini, dari seluruh negara di dunia mayoritas terjangkit virus covid-19. Dan pemerintah memberikan himbauan kepada seluruh masyarakat untuk mematuhi protokol kesehatan yang telah ditetapkan. Misalnya melakukan jaga jarak satu sama yang lain, menggunakan masker, selalu mencuci tangan, atau ingin lebih praktis memakai hand sanitizier atau alcohol spray, dll. Dan dengan himbauan ini bisa memutus rantai penyebaran virus covid-19 dengan selalu disiplin dengan peraturan yang ditetapkan. Dalam Islam terdapat peraturan didalam kehidupan, salah satunya dalam menjaga kesehatan dan kebersihan didalam diri sendiri maupun di lingkungan. Kesehatan merupakan nikmat Tuhan yang diberikan kepada manusia. Dari dampak covid-19 inilah diingatkan kembali untuk selalu menjaga kebersihan, kesehatan, karena semua itu juga termasuk kedalam iman. ${ }^{10}$

Wabah covid-19 memberikan dampak bagi semuanya, terutama dalam bidang pendidikan, khususnya pendidikan Islam. Ditengah pandemi covid-19 pendidikan Islam

\footnotetext{
${ }^{9}$ Samrin, "Pendidikan Agama Islam Dalam Sistem Pendidikan Nasional Di Indonesia," Jurnal Al-Ta'dib 8, no. 1 (2015): 112.

${ }^{10}$ Abdusshomad, "Pengaruh Covid-19 Terhadap Penerapan Pendidikan Karakter Dan Pendidikan Islam," 113.
} 
harus bisa menanggapi semua kondisi yang dikeluhkan masyarakat. Pendidikan Islam seperti bimbingan yang dijalankan dengan rasa sadar kemudian menggunakan sebagian wawasan dan pengalaman, pengetahuan, mengenal, memahami, menghayati, dan mengimani ajaran Islam. Dan disini pendidikan Islam merupakan bagian dari salah satu materi yang memiliki tujuan untuk meningkatkan akhlak mulia serta memiliki nilai-nilai spiritual. Dan untuk memelihara manusia secara fisik agar selalu sehat dan bugar dengan menjaga kesehatan dan kebersihan. ${ }^{11}$

Jadi, dengan adanya pandemi covid-19 ini memberikan sebuah pembelajaran yang secara tidak langsung terjadi pada semua. Yaitu agar selalu mendekatkan diri kepada Tuhan dengan meminta kepadanya memohon kepadanya, berikhtiyar, tawakal, sabar, menjaga kebersihan, menghargai saudara-saudara diluar sana yang mayoritas terdampak covid-19. Dengan covid-19 seakan-akan mengingatkan kembali, bahwa sekarang ini banyak yang lupa dengan ajaran-ajaran Islam terutama lupa dengan Tuhan semesta.

\section{UPAYA PENCAPAIANNYA PENDIDIKAN ISLAM DALAM PENDIDIKAN NASIONAL DI MASA PANDEMI COVID}

Pendidikan Islam dalam pendidikan nasional berupaya dalam pencapaiannya ditengah wabah pandemi covid-19, yang memiliki tujuan untuk menumbuhkan, meningkatkan ataupun memupuk pengetahuan dari sebuah penghayatan, pemahaman serta pengalaman peserta didik tentang agama dan nilai pendidikan lainnya sehingga bisa manjadi manusia yang mampu mengembangkan potensinya, maupun berkembang dalam hal keimanan, ketaqwaan kepada Tuhan Yang Maha Esa, menjadi manusia yang bertanggung jawab untuk bangsa dan negara. Pendidikan Islam sering dipandang tidak memiliki paksaan dalam memproses sistem kependidikan, sehingga terkesan diremehkan. Dan ini seakan-akan perwujudan yang sangat eronis dalam perjuangan menuju cita-cita dan tujuan pendidikan Nasional.

Pendidikan agama yang dilakukan di sekolah merupakan bagian yang integral untuk mencapai tujuan pendidikan nasional. Menurut Undang-undang nomor 20 tahun 2003 tentang pendidikan Nasional pasal 1 merupakan usaha sadar dan terencana untuk mewujudkan suasana belajar dan proses pembelajaran agar peserta didik secara aktif mengembangkan potesi dirinya untuk memiliki kekuatan spiritual keagamaan, pengendalian diri, kepribadian, kecerdasan, akhlak mulia, serta ketrampilan yang diperlukan dirinya , masyarakat, bangsa, dan negara. Pendidikan agama Islam sering disebut pendidikan agama yang dilaksanakan sejak sekolah dasar sampai perguruan tinggi selama ini secara kuantitatif telah menyumbang tidak kecil terhadap peningkatan kehidupan keagamaan. ${ }^{12}$

\footnotetext{
${ }^{11}$ Hj Rt Bai Rohimah, "Solusi Pembelajaran Agama Islam Online di Masa Pandemi," Prosiding Seminar Nasional Pendidikan FKIP Universitas Sultan Ageng Tirtayasa 3, no. 1 (November 25, 2020): 342.

${ }^{12}$ Elly Manizar, "Optimalisasi Pendidikan Agama Islam di Sekolah," Tadrib: Jurnal Pendidikan Agama Islam 3, no. 2 (February 15, 2018): 259, https://doi.org/10.19109/tadrib.v3i2.1796.
} 
Namun demikian tidak berarti bahwa pelaksanaan pendidikan agama itu telah memenuhi keseluruhan cita-cita kebangsaan ini. Dalam kenyataannya pendidikan agama Islam belum sepenuhnya berlangsung pada alur yang mampu mengantarkan peserta didik pada pengamalan nilai-nilai yang terdapat dalam ajaran Islam. Pendidikan agama belum sepenuhnya diarahkan pada proses pembentukan yang komprehensip sebagai makna dari pendidikan Islam itu sendiri. Mengapa pelakaksanaan pendidikan agama belum memenuhi keseluruhan cita-cita maupun nilai-nilai yang terdapat dalam ajaran Islam karena kondisi pandemi covid-19 memaksa para pemangku kebijakan di bidang pendidikan untuk dapat menyesuaikan diri dalam melaksanakan proses pembelajaran. Hal inilah yang menyebabkan pelaksanaan pendidikan belum sesuai dengan apa yang di harapkan.

Masa pandemi covid-19 ini membuat pola pendidikan berubah, semula proses belajar mengajar dilakukan dengan tatap muka, tetapi kini, proses belajar mengajar dilakukan secara jarak jauh atau daring. Dengan hal ini pelaksanaan pendidikan agama Islam di sekolah masih menunjukkan keadaan yang memprihatinkan, banyak faktor yang menyebabkan keprihatinan itu dari segi jam pembelajaran yang disediakan di sekolah serta sumber referensi atau pemahan materi yang terbatas. Dengan demikian pendidikan agama merupakan tugas dan tanggung jawab bersama. Artinya pendidikan bukan hanya tanggung jawab guru agama saja, melainkan juga guru-guru bidang studi lainnya. Dari hasil pendidikan agama yang dilakukan secara bersama-sama ini dapat membentuk pengetahuan, sikap, perilaku, dan pengalaman keagaan yang baik dan benar. Peserta didik akan akan mempunyai akhlak mulia, perilaku jujur, disiplin dan semangat keagamaan sehingga menjadi dasar untuk meningkatkan kualitas dirinya.

Kemajuan suatu bangsa hanya dapat dicapai melalui penataan pendidikan yang baik. Upaya peningkatan mutu pendidikan itu diharapkan dapat menaikkan harkat dan martabat manusia Indonesia termasuk penataan pendidikan agama Islam. Untuk mencapai tujuan pendidikan agama itu, proses pendidikan dan peran lembaga- lembaga pendidikan sangat penting dan menempati kedudukan strategis. Kedudukan strategis itu telah menempatkan segenap pihak yang terkait baik pada tingkat perencanaan, penyusunan program maupun oelaksanaan di lapangan harus adaptif terhadap perubahan.

Pada dasarnya, keberhasilan pendidikan agama Islam dapat terwujud apabila seluruh aspek yang berhubungan langsung dengan pendidikan dapat bekerja sama dan saling membantu dari berbagai pikak antara lain pihak sekolah dengan orang tua peserta didik, lembaga dengan masyarakat dan lain sebagainya, demi meningkatkan keberhasilan pendidikan Agama Islam. ${ }^{13}$

Sebagaimana sudah di ketahui bahwa pelaksanaan proses pendidikan itu masih di hadapkan pada berbagai hal, baik secara langsung maupun tidak langsung, baik berkaitan dengan hal-hal didalam lembaga pendidikan maupun hal-hal diluar lembaga

13 Raudlatul Jannah, "Upaya Meningkatkan Keberhasilan Pembelajaran Pendidikan Agama Islam," Madrosatuna: Journal of Islamic Elementary School 1, no. 1 (December 7, 2017): 48, https://doi.org/10.21070/madrosatuna.v1i1.1211. 
pendidikan sehingga pembentukan manusia yang yang beriman dan bertakwa belum pernah berjalan mulus sebagaimana yang di harapkan, itu semua menjadi tantangan yang harus diatasi karena komitmen kenbangsaan kita terhadap amanat konstitusional untuk memperjuangkan cita-cita nasional. Oleh karena itu optimalisasi pendidikan agama harus dilakukan dengan mengoptimalkan fungsinya dan memaksimalkan program dan kegiatannya dengan upaya-upaya sebagai berikut:

1. Kesejahteraan Sejawat Di Sekolah

Dalam pelaksanaan kegiatan pembelajaran pendidikan agama akan berhasil dengan baik manakala adanya kerjasama dengan semua pihak yang terkait di antaranya sejawat yaitu guru-guru di tiap sekolah, dimana mereka ini adalah sejawat dan mitra guru PAI. Setiap guru seharusnya memiluk amanah dan tanggung jawab untuk memperjuangkan tercapainya tujuan pendidikan nasional sekalipun tanggung jawab formal dan pembidangan tugas dibedakan. Pelaksanaan penidikan islam memerlukan dukungan dari sumua pihak. Ujung tombak dan penanggung jawab formal pendidikan agama di sekolah adalah guru pendidikan agama. Namun itu tidak berarti bahwa guru-guru yang lain tidak terkait dengan proses pendidikan yang bertujuan menjadikan peserta didik manusia-manusia yang beriman dan bertakwa kepada Tuhan Yang Maha Esa.

Tiap guru memikul tanggung jawab moral untuk mendukung baik secara langsung maupun tidak langsung, baik secara perorangan maupun secara lembaga terslenggaranya proses pendidikan agama yang memang tidak hanya terbatas di dalam penyajian mata pelajaran dalam kelas. Oleh karena itu, dalam hal ini guru memang diharapkan benar kesertaanya sebagai menifestasi tanggung jawabnya sebagai ujung tombak proses pendidikan di sekolah. Apalagi jika di suatu sekolah dikembangkan oleh guru pendidikan agama di berbagai kegiatan yang berusaha membimbing dan membiasakan peserta didik mengamalkan nilai-nilai agama maka kemitraan para guru semakin dibutuhkan untuk mendukung nya. Pada dasarnya setiap guru wajib memberikan dukungan pada segenap program dan kegiatan yang merupakan penjabaran kreatif untuk mencapai tujuan pendidikan nasional.

2. Sarana Penunjang Kegiatan

Melengkapi sarana pembinaan agama islam di sekolah. Umtuk mendukung kegiatan pendidikan islam di sekolah, pendidikan agama memerlukan sarana penunjang yang akan memungkinkan kegiatan-kegiatan dapat dilaksanakan. Sarana yang dimaksud merupakan sumber-sumber seperti buku-buku yang memadai, sarana laboraturium agama dengan menyiapkan perlengkapan yang menunjang materi pembelajaran, seperti perlengkapan sholat, perlengkapan sholat jenazah, peralatan ibadah haji, dan peralatan-peralatan yang di butuhkan oleh peserta didik guna mendalami pengetahuan dan ketrampilan keagamaan. 


\section{Dukungan Pihak Terkait}

Langkah-langkah yang ditempuh, kebijaksanaan yang diambil, program aksi yang dilaksanakan merupakan bagian dari perjuangan besar untuk membangunmasa depan yang lebih baik, manusia dan masyarakat indonesia yang tangguh menghadapi tantangan kehidupan yang kian kompleks pada masa depan. Itu akan tergantung pada usaha, kebijaksanaan, pelaksanaan tugas yang dilakukan pada hari ini.untuk itu perlu ketulusan masyarakat luas untuk menunjang kemauan para pemegang kekuasaan dan pengambil kebijaksanaan, kreatifitas dan kberanian serta kesungguhan para guru dan kepala sekolah. Semua itu saling berkaitan, saling mengisi dan saling mendukung, bisa saja suatu sekolah memiliki kemampuan mengembangkan dan meningkatkan kegiatan, tetapi tidak dapat ditularkan ke sekolah lain tanpa didukung oleh keputusan pihak berwenang.

4. Melakukan Evaluasi

Mengenai evaluasi pendidikan agama islam ini terkadang terjadi hal-hal yang diluar dugaan. Misalnya ada peserta didik yang jarang sekolah, malas, dan merasa terpaksa mengikuti pelajaran agama, tapi ketika di evaluasi dia mendapatkan nilai yang lebih tinggi di bandingkan dengan peserta didik yang rajin belajar agama.artinya yang salah itu adalah evaluasinya karena yang dilakukan adalah unsur kognitifnya saja. Oleh karena itu evaluasi pendidikan agama islam jangan hanya mengandalkan evaluasi kognitif saja, tetapi juga harus dievaluasi juga sikap, praktek, atau ketrampilannya dan sikapnya. Evaluasi ini sebetulnya menentukan ststus peserta didik tentang hasil belajarnya itu apakah sudah mencapai tujuan yang ingin di capai atau tidak. Tujuan agama itu adalah supaya peserta didik bisa menjalankan proses pembelajaran dengan baik maka evaluasinya harus sesuai dan evaluasinya itu bukan hanya hafal tentang kaidah-kaidah tentang kemampuan kognitif saja tetapi juga bersifat praktikal.

Berkaitan dengan evaluasi pendidikan agama islam, ada usulan yang kuat dari berbagai kalangan agar pendidikan agama islam sebaiknya masuk pada ujian nasional, sehingga menjadi bahan untuk dipertimbangkan peserta didk lulus atau tudak lulus di suatu lembaga pendidikan. ujiannya jangan sekedar mengukur kemempuan kognitif saja, melainkan juga kemempuan yang bersifat psikomotor, prakter, dan perilaku, serta sikap peserta didik sebagai orang yang menganut ajaran agama islam. Namun, dalam pelaksanaan program pendidikan agama di berbagai pendidikan agama di berbagai sekolah indonesia, belum berjalan seperti yang diharapkan, karena berbagai kendala dalam bidang kemampuan pelaksanaan metode, sarana fisik dan nonfisik, di samping suasana lingkungan pendidikan yang kurang menunjang aksesnya pendidikan mental-spiritual dan moral.

Keberhasilan di tandai dengan tercapainya tujuan kemampuan yang diharapkan. Ketercapaian tujuan dibuktikan jika lulusan dapat menunjukkan kemampuan dalam melaksanakan tugas yang telah ditentukan. Pendidikan agama islam di sekolah atau madrasah bertujuan untuk menumbuhkan dan meningkatkan keimana melalui pemberian dan penumpukan pengetahuan, penghayatan, 
pemahaman serta pengelaman peserta didik tentang agama islam sehingga menjadi manusia muslim yang terus berkembang dalam hal keimanan, ketakwaanya, berbangsa dan bernegara serta untuk dapat melanjutkan ke jenjang pendidikan yang lebih tinggi. ${ }^{14}$

\section{KESIMPULAN}

Upaya pencapaian tujuan pendidikan Islam dalam pendidikan nasional di masa pandemi covid-19 ini dapat di simpulkan bahwa pendidikan Islam merupakan sebuah proses untuk merubah tingkah laku individu pada kehidupan pribadi, masyarakat, dan alam sekitarnya. Dengan cara adanya sebuah pengajaran untuk dijadikan suatu aktivitas yang bersifat dasar dan juga di jadikan untuk berbagai bidang pekerjaan yang bisa dilandasi dengan Pendidikan keahlian yang dimiliki. Pendidikan islam dapat membentuk kepribadian setiap umat muslim, dan bahkan pendidikan Islam bisa merubah sikap dan tingkah laku agar sesuai dengan ajaran Islam.

Pendidikan Nasional merupakan pendidikan yang mempunyai keterkaitan dengan kebudayaan indonesia. Pendidikan nasional mempunyai keseluruhan yang di padu dari semua satuan dan kegiatan pendidikan yang berkaitan dengan sistem lainnya nntuk tercapainya sebuah tujuan yang telah ditetapkan. Penddikan nasional erfungsi untuk mengembangkan setiap kemampuan dan meningkatkan mutu kehidupan masyarakat indonesia dalam rangka mewujudkan tujuan pendidikan Nasional.

Pendidikan Islam dalam Pendidikan Nasional di masa pandemic covid-19 ini mempunyai arti-arti penting yaitu yang pertama adalah nilai-nilai yang terkandung dalam Pancasila itu sebagai dasar nilai dengan agama Islam yang berarti Tauhid. Pada saat covid-19 sekarang ini harus percaya dan yakin pada Allah bahwa Tuhan itu ada dan setiap kejadian atau musibah yang terjadi saat ini berasal dari-Nya. Kedua kita harus tetap menjadi manusia yang memiliki potensi dan menjadi manusia yang berguna dalam masyarakat dan menjadi manusia yang bermartabat baik secara jasmani maupun rohani serta mampu mengembangkan potensi menjadi manusia yang berakhlaq, beriman, bertaqwa dan juga memiliki rasa tanggung jawab.

Untuk pencapaian upaya pendidikan Islam dalam pendidikan nasional yaitu dengan cara mengoptimalkan fungsi pendidikan agama Islam dan memaksimalkan program melalui upaya-upaya kesetaraan sejawat di sekolah, sarana penunjang kegiatan, dukungan dari pihak yang berkaitan, melakukan evaluasi. Keberhasilan ditandai dengan tercapainya tujuan kemampuan yang diharapkan. Dengan demikian untuk mencapai sebuah keberhasilan sangat memerlukan berbagai upaya dan pengorbanan, serta keuletan dalam menghadapi tantangan. Dengan tercapainya tujuan-tujuan pendidikan Islam tersebut, maka keberhasilan pendidikan Islam dapat dirasakan oleh semua masyarakat muslim kususnya dan Masyarakat Indonesia secara umum.

${ }^{14}$ Jannah, 49-50. 


\section{DAFTAR PUSTAKA}

Abdusshomad, Alwazir. "Pengaruh Covid-19 Terhadap Penerapan Pendidikan Karakter Dan Pendidikan Islam." QALAMUNA: Jurnal Pendidikan, Sosial, Dan Agama 12, no. 2 (June 3, 2020): 107-15. https://doi.org/10.37680/qalamuna.v12i2.407.

Anwar, Syaiful, and Agus Salim. "Pendidikan Islam Dalam Membangun Karakter Bangsa Di Era Milenial." Al-Tadzkiyyah: Jurnal Pendidikan Islam 9, no. 2 (January 4, 2019): 233. https://doi.org/10.24042/atjpi.v9i2.3628.

Awwaliyah, Robiatul, and Hasan Baharun. "Pendidikan Islam Dalam Sistem Pendidikan Nasional Pendidikan Islam Dalam Sistem Pendidikan Nasional (Telaah Epistemologi Terhadap Problematika Pendidikan Islam).” Jurnal Ilmiah Didaktika. Vol. 19, January 14, 2018. https://doi.org/10.22373/JID.V19I1.4193.

Gojali, Nanang. Tafsir Dan Hadits Tentang Pendidikan. Bandung: CV. Pustaka Setia, 2013.

Ikhwan, Afiful. "Kajian Sosio-Historis Pendidikan Islam Indonesia Era Reformasi." EDUKASI : Jurnal Pendidikan Islam (e-Journal) 5, no. 1 (October 13, 2017): 1432.

Inayatulloh, Siti. "Menimbang Penerapan Pendidikan Islam Dalam Sistem Pendidikan Nasional." Jurnal Manajemen Pendidikan Islam 1, no. 2 (2016).

Jannah, Raudlatul. "Upaya Meningkatkan Keberhasilan Pembelajaran Pendidikan Agama Islam." Madrosatuna: Journal of Islamic Elementary School 1, no. 1 (December 7, 2017): 47. https://doi.org/10.21070/madrosatuna.v1i1.1211.

Kholis, Nur. "Paradigma Pendidikan Islam dalam Undang-Undang Sisdiknas 2003." Jurnal Kependidikan 2, no. 1 (January 1, 1970): 71-85. https://doi.org/10.24090/jk.v2i1.542.

Manizar, Elly. “Optimalisasi Pendidikan Agama Islam di Sekolah.” Tadrib: Jurnal Pendidikan Agama Islam 3, no. 2 (February 15, 2018): 251. https://doi.org/10.19109/tadrib.v3i2.1796.

Rt Bai Rohimah, Hj. "Solusi Pembelajaran Agama Islam Online di Masa Pandemi." Prosiding Seminar Nasional Pendidikan FKIP Universitas Sultan Ageng Tirtayasa 3, no. 1 (November 25, 2020): 340-50.

Samrin. "Pendidikan Agama Islam Dalam Sistem Pendidikan Nasional Di Indonesia." Jurnal Al-Ta'dib 8, no. 1 (2015). 